\title{
Pelaksanaan Quality Control Proses Pembelajaran Pada \\ Pascasarjana Universitas Islam Negeri (UIN) Alauddin Makassar
}

\section{PELAKSANAAN QUALITY CONTROL PROSES PEMBELAJARAN PADA PASCASARJANA UNIVERSITAS ISLAM NEGERI (UIN) ALAUDDIN MAKASSAR}
Ahmad Yani
Azhar Arsyad
Syamsudduha
Arifuddin, S

\begin{abstract}
Penelitian ini mengkaji tentang quality control Proses Pembelajaran, yang terdiri atas 3 (tiga) aspek yakni: perencanaan pembelajaran, pelaksanaan, dan evaluasi hasil pembelajaran. Dengan tujuan untuk menjelaskan pelaksanaan quality control pada Pascasarjana Universitas Islam Negeri (UIN) Alauddin Makassar dari ketiga aspek tersebut. Penelitian ini adalah penelitian kualitatif deskriptif dengan menggunakan pendekatan fenomenologi. Teknik pengumpulan data yakni observasi partisipatorik, wawancara terbuka, dan studi dokumentasi. Penetapan sumber data dilakukan secara purposive sampling random dan teknik analisis data menggunakan analisis teori Miles dan Huberman, yakni proses pengolahan data melalui tiga tahap yakni reduksi data, penyajian data, dan verifikasi/penarikan kesimpulan.
\end{abstract}

Hasil penelitian terkait quality control terhadap proses pembelajaran menunjukkan bahwa pelaksanaan quality control pada perencanaan pembelajaran, pelaksanaan pembelajaran dan evaluasi hasil pembelajaran telah dilaksanakan sesuai standar yang ditetapkan baik internal maupun berdasarkan standar nasional pendidikan tinggi (SNPT), dengan indikator tersedianya program tahunan maupun semester, dan kalender akademik yang menjadi acuan dalam proses pembelajaran, penyediaan sarana dan prasarana pembelajaran, dan tersedianya RPS/Silabus. Adapun program yang dilakukan Pascasarjana terkait dengan quality control, yakni: 1) pelaksanaan rapat edukasi setiap awal tahun akademik berjalan yang bertujuan untuk mengevaluasi pembelajaran yang telah terlaksana sekaligus mendengarkan masukan-masukan dan aspirasi dosen dalam rangka peningkatan mutu dan proses penyelenggaraan pendidikan, 2) control terhadap kehadiran dosen kegiatan pembelajaran, 3) control pelaksanaan tugas dosen dengan mekanisme penilaian course evaluation survey yang terintegrasi dengan sistem informasi akademik, 3) control yang dilakukan oleh pengelola program studi terkait dengan terhadap pelaksanaan pembelajaran baik secara langsung di ruangan, maupun melalui absensi setelah perkuliahan dilaksanakan, 4) control yang dilakukan oleh ketua program studi terkait kesesuaian materi yang diberikan oleh dosen dengan silabi yang telah dibuat dan disetujui melalui instrumen jurnal perkuliahan, 5) kontrol pelaksanaan evaluasi terkait ujian yang dilaksanakan baik ujian semester maupun ujian lainnya seperti ujian kualifikasi proposal, hasil tutup maupun ujian terbuka (promosi). Berdasarkan hasil penelitian tersebut, dapat dinyatakan bahwa pelaksanaan quality control di Pascasarjana Universitas Islam Alauddin Makassar dilaksanakan dengan menerapkan konsep mutu yang lebih mengacu pada standar-standar, baik itu standar nasional pendidikan tinggi maupun standar mutu internal yang ditetapkan olen lembaga, dan belum sepenuhnya mempertimbangkan kebutuhan pasar serta keinginan konsumen 
(stakeholders). Hal ini menguatkan teori mutu yang dikemukakan oleh Philip B. Crosby yang menyatakan bahwa mutu adalah kesesuaian dengan yang dipersyaratkan/distandarkan. Penelitian ini diharapkan dapat berimplikasi terhadap upaya peningkatan mutu layanan administrasi akademik melalui penguatan sistem dan kebijakan pengelolaan pendidikan yang bermutu dan berdaya saing.

\section{A. PENDAHULUAN}

Pendidikan adalah merupakan persoalan yang sangat urgen dalam kehidupan suatu bangsa. Maju tidaknya suatu bangsa sangat tergantung pada pendidikan bangsa tersebut. Hal ini dilatarbelakangi oleh fakta bahwa pendidikan dapat menghasilkan sumber daya manusia yang berkualitas dan sumber daya manusia yang berkualitas merupakan modal utama dalam kemajuan suatu bangsa.

Pendidikan menduduki posisi penting dalam Islam, yaitu sebagai sarana pembangunan umat yang cerdas dan berpengetahuan luas agar menjadi rahmat bagi semesta. Terkait dengan kualitas sumberdaya manusia, Islam memandang bahwa pembinaan sumberdaya manusia tidak dapat dilepaskan dari pemikiran mengenai manusia itu sendiri, dengan demikian Islam memiliki konsep yang sangat jelas, utuh dan komprehensif mengenai pembinaan sumber daya manusia.

Permasalahan pendidikan yang saat ini sedang dihadapi oleh bangsa Indonesia adalah rendahnya mutu pendidikan pada setiap jenjang dan satuan pendidikan. Berbagai usaha telah dilakukan, namun sejauh ini pencapaian yang diharapkan masih jauh dari yang diharapkan. Suatu lembaga pendidikan baik pendidikan umum maupun pendidikan keagamaan menjadikan mutu sebagai agenda terpenting dalam pengelolaan dan penyelenggaraan pendidikan. Dan hal tersebut dapat terwujud dengan memperhatikan aspek input, proses dan output. Selain hal tersebut, faktor manajemen merupakan salah satu faktor kunci untuk meraih mutu secara optimal khususnya pada lembaga pendidikan tinggi.

Mencermati perkembangan pendidikan dewasa ini, pendidikan nasional tengah menghadapi isu yang sensitif terkait dengan mutu pendidikan, relevansi pendidikan, dan perilaku pemimpin pendidikan. Hal tersebut sangat kontradiktif dengan Undangundang No. 20 Tahun 2003 tentang Sistem pendidikan Nasional yang menyatakan bahwa "Pendidikan Nasional berfungsi mengembangkan kemampuan dan membentuk watak serta peradaban bangsa dalam rangka mencerdaskan kehidupan bangsa, bertujuan untuk berkembangnya potensi peserta didik agar menjadi manusia yang beriman dan bertaqwa kepada Tuhan Yang Maha Esa, berakhlak mulia, sehat, berilmu, cakap, kreatif, mandiri, dan menjadi warga Negara yang demokratis serta bertanggungjawab".

Permasalahan rendahnya mutu yang dihadapi dalam dunia pendidikan, seperti mutu lulusan, mutu proses pembelajaran, mutu bimbingan dan latihan, mutu profesionalisme, serta kinerja pendidik dan tenaga kependidikan tersebut terkait dengan mutu manajerial para pimpinan pendidikan, keterbatasan dana, sarana, dan prasarana, fasilitas pendidikan, media, sumber belajar, alat dan bahan latihan, iklim sekolah, lingkungan pendidikan, serta dukungan dari pihak-pihak yang terkait dengan pendidikan tersebut berujung pada rendahnya mutu lulusan. Mutu lulusan yang rendah dapat menimbulkan berbagai masalah, seperti lulusan tidak dapat melanjutkan studi, tidak dapat menyelesaikan studinya pada jenjang yang lebih tinggi, tidak diterima di dunia kerja, diterima bekerja tapi tidak berprestasi, tidak dapat mengikuti perkembangan masyarakat dan tidak produktif. Lulusan tidak produktif akan menjadi beban masyarakat, menambah biaya kehidupan dan kesejahteraan masyarakat, serta memungkinkan menjadi warga yang tersisih dari masyarakat.

${ }^{1}$ Republik Indonesia, Undang-Undang Nomor 20 Tahun 2003 tentang Sistem Pendidikan Nasional; Bab I Pasal 3 (Cet. VI; Jakarta: Sinar Grafika Offset, 2014), h. 7. 


\section{Pelaksanaan Quality Control Proses Pembelajaran Pada Pascasarjana Universitas Islam Negeri (UIN) Alauddin Makassar}

Dalam rangka menunjang kemajuan perkembangan sistem perguruan tinggi yang baik, penerapan sistem manajemen mutu perguruan tinggi sangatlah dibutuhkan, untuk menjamin terlaksananya perbaikan mutu perguruan tinggi secara berkelanjutan. Penerapan prinsip manajemen mutu dalam suatu institusi perguruan tinggi menjamin terlaksananya perbaikan mutu secara berkelanjutan. Institusi harus menyusun sistem mutu dalam bentuk pedoman mutu (quality manua), sebagai acuan bagi semua unsur yang terlibat dalam pencapaian standar-standar kinerja mutu yang ditetapkan. Implementasi sistem manajemen mutu harus diaudit secara berkala dalam rangka memperoleh masukan untuk manajemen review untuk penyempurnaan sistem itu sendiri. ${ }^{2}$

Salah satu pendekatan yang efektif untuk dikembangkan dalam institusi pendidikan Islam adalah pola manajemen berbasis industri, yaitu pendekatan Total Quality Management atau Manajemen Mutu Terpadu sebagai sebuah sistem manajemen dalam upaya memaksimalkan daya saing melalui perbaikan secara berkesinambungan untuk memperoleh mutu yang optimal dengan melibatkan keseluruhan unsur dan stakeholders organisasi di bawah satu visi bersama. ${ }^{3}$ Secara filosofis, konsep TQM menekankan pada pencarian secara konsisten terhadap perbaikan yang berkelanjutan untuk mencapai kebutuhan dan kepuasan pelanggan. ${ }^{4}$ Filosofi inilah yang oleh sebagian pakar pendidikan dapat dijadikan acuan dasar (bencmarking) untuk menciptakan lembaga pendidikan yang bermutu yakni dengan pendekatan Total Quality Management.

Peningkatan mutu dan kualitas pendidikan merupakan dambaan seluruh penyelenggara pendidikan tidak terkecuali pendidikan tinggi sebab hanya dengan pengelolaan pendidikan yang bermutu, mereka dapat memenangkan persaingan, namun upaya meningkatkan mutu tersebut tidaklah mudah. Upaya peningkatan mutu memerlukan usaha yang serius dan bersungguh-sungguh dengan melibatkan unsurunsur baik internal maupun eksternal. Berbagai upaya perbaikan mutu pendidikan telah banyak dilakukan, akan tetapi pada kenyataannya kurang atau bahkan tidak berhasil. Setidaknya terdapat beberapa kelemahan umum yang terjadi pada perguruan tinggi (PT) di Indonesia tidak dapat menjadi PT yang berkelas dunia, di antaranya: a. sistem pengelolaan yang buruk, b. sumber daya yang rendah, c. penguasaan bahasa internasional yang rendah, d. pendanaan yang seret, e. peran serta masyarakat yang masih sangat terlalu minim, dan $\mathrm{f}$. pola pikir sebahagian civitas akademika yang masih perlu ditransform dan di asah terus menerus. ${ }^{5}$ Secara singkat dapat dikatakan bahwa kompleksitasnya cakupan permasalahan pendidikan seringkali tidak dapat terpikirkan secara utuh dan akurat oleh penyelenggara pendidikan. Perguruan tinggi tidak hanya perlu dilihat sebagai pusat ilmu pengetahuan, pusat penelitian, dan pusat pengabdian kepada masyarakat, tetapi juga suatu entitas korporat "penghasil ilmu pengetahuan" yang perlu "bersaing" dalam memberikan pelayanan berupa jasa di bidang pendidikan yang bermutu dan berkualitas. Dalam dunia pendidikan, beberapa teori manajemen yang telah diterapkan, antara lain Total Quality Management Bechmarking Management. School Based Management. Reinventing School. Dari keempat teori yang tergolong modern tersebut dapat ditemukan beberapa prinsip yang penting untuk diterapkan dalam manajemen pendidikan sebagai berikut:

\footnotetext{
${ }^{2}$ Buyung Syukron, Implementasi Manajemen Mutu Terpadu: Studi Transformatif pada Perguruan Tinggi (Jurnal Penelitian, Vol. 10, No. 2, Agustus 2016), h. 233.

${ }^{3}$ M. Arifin, Kapita Selekta Pendidikan Islam (Jakarta; Bulan Bintang, 1999), h. 123.

${ }^{4}$ Deden Makbuloh, Manajemen Mutu Pendidikan Islam; Model Pengembangan Teori dan Aplikasi Sistem Penjaminan Mutu (Cet. I; Jakarta: PT. Raja Grafindo Persada, 2011), h. 4

${ }^{5}$ Azhar Arsyad, Membangun Universitas Menuju Peradaban Islam Modern; Pendidikan Tinggi dalam Konteks Memperkuat Daya Saing Bangsa, h. 119.
} 
1. Prinsip berorientasi pada pencapaian mutu yang tinggi, yang dicapai melalui suatu tim kerja yang solid dan kepemimpinan yang andal. Dengan kata lain, suatu lembaga pendidikan yang baik dan unggul adalah lembaga pendidikan yang memiliki budaya mutu.

2. Prinsip standar mutu yang baku sehingga dapat memberikan keyakinan dan kepuasan kepada orang yang menginginkannya. Prinsip ini secara sungguh-sungguh harus dipegang teguh dan dilaksanakan sebaik-baiknya secara terus menerus.

3. Prinsip pemberikan kepercayaan dan wewenang kepada mereka yang lebih menghayati dan mengetahui terhadap yang dikerjakannya yaitu mereka yang menginginkan keahlian dan kemapuan untuk melaksanakannya. ${ }^{6}$

Berdasarkan uraian tersebut, secara jelas bahwa dasar dari pelaksanaan manajemen pendidikan adalah pemberian jasa berupa layanan yang berkualitas tinggi kepada pihak-pihak yang membutuhkannya. Pengelolaan pendidikan yang bermutu dan berdaya saing tinggi haruslah menjadi agenda utama dalam penyelengaraan pendidikan khususnya pendidikan tinggi. Pihak-pihak yang berkompeten dalam hal ini pengelola Pascasarjana UIN Alauddin Makassar haruslah segera berbenah diri dan merubah paradigmanya dengan memberikan pelayanan yang optimal khususnya dibidang akademik berdasarkan filosofis bahwa peningkatan kualitas harus dilakukan secara menyeluruh dari semua unsur sejak dini dan secara terpadu dan berkesinambungan, dengan harapan Pascasarjana UIN Alauddin Makassar kedepannya bisa melampaui harapan dengan memberikan pelayanan yang optimal kepada seluruh stakeholders.

Mutu luaran akan dipengaruhi oleh sejauh mana lembaga mampu mengelola seluruh potensi secara optimal mulai dari tenaga kependidikan, peserta didik, proses pembelajaran, sarana pendidikan, keuangan dan termasuk hubungannya dengan masyarakat. Saat ini, lembaga pendidikan Islam harus mampu merubah paradigma baru pendidikan yang berorientasi pada mutu semua aktivitas yang berinteraksi di dalamnya, seluruhnya mengarah pencapaian pada mutu. Dalam rangka mewujudkannya, dianggap perlu untuk mengidentifikasi hal-hal terkait dengan permasalahan kaitannya dengan implementasi quality control terhadap penyelenggaraan pendidikan pada Pascasarjana UIN Alauddin dalam aspek: input (masukan), proses (transaction), dan output (lulusan), dengan rincian sebagai berikut:

Pada aspek input (masukan), beberapa permasalahan yang diidentifikasi yakni: mahasiswa, kurikulum, tenaga kependidikan, pada aspek proses yang mempengaruhi mutu adalah perencanaa pembelajaran, pelaksanaan pembelajaran, dan evaluasi pembelajaran dan pada aspek output adalah rata-rata IPK, masa studi, dan Presntase kelulusan.

Permasalahan tersebut secara langsung berkaitan dengan upaya pengembangan mutu pendidikan. Berangkat dari hal inilah sehingga penulis tertarik dan bermaksud melakukan penelitian disertasi guna menggali lebih dalam hal-hal yang berkaitan dengan pelaksanaan Quality control pada Pascasarjana Universitas Islam Negeri (UIN) Alauddin Makassar.

Penelitian difokuskan membahas tentang Quality control proses pembelajaran yang dilakukan oleh pengelola Pascasarjana UIN Alauddin Makassar. Fokus utama ini yang dijabarkan dalam tiga fokus penelitian yang meliputi perencanaan pembelajaran, pelaksanaan pembelajaran dan evaluasi pembelajaran.

Berdasarkan fokus penelitian tersebut, maka perlu dideskripsikan masingmasing-masing fokus penelitian dari aspek proses terkait pelaksanaan quality control pada Pascasarjana Universitas Islam Negeri (UIN) Alauddin Makassar, meliputi 3 aspek yakni perencanaan pembelajaran, pelaksanaan pembelajaran, dan evaluasi hasil pembelajaran.

${ }^{6}$ Abudddin Nata, Pendidikan dalam Persfektif Al-Qur'an, h. 275-276. 


\section{Pelaksanaan Quality Control Proses Pembelajaran Pada Pascasarjana Universitas Islam Negeri (UIN) Alauddin Makassar}

\section{TINJAUAN TEORITIS}

\section{A. Konseptualisasi Mutu}

\section{Defenisi Mutu}

Dalam dunia persaingan global saat ini, orang pada umumnya membicarakan tentang "mutu" terutama berhubungan dengan pekerjaan yang menghasilkan produk dan/atau jasa, hal ini disebabkan karena suatu produk dibuat karena ada yang membutuhkan, dan kebutuhan tersebut berkembang seiring dengan tuntutan penggunanya.

Definisi mutu memiliki konotasi yang bermacam-macam tergantung orang yang memaknainya. Mutu berasal dari bahasa Latin yakni qualis, yang artinya what kind of. Menurut pendapat W. Edward Deming sebagaimana yang dikutip Husaini, mutu adalah kesesuaian dengan produk pasar. ${ }^{7}$ Philip B. Crosby sebagaimana dikutip dalam Umiarso \& Iman Gojali, kualitas adalah adalah conformance to requirement yaitu sesuai dengan yang diisyaratkan atau di standarkan. Artinya, suatu produk memiliki kualitas apabila sesuai dengan standar kualitas yang telah ditentukan, meliputi, bahan baku, proses produksi, dan bahan jadi, ${ }^{8}$ sedangkan Joseph M. Juran mengemukakan mutu suatu produk adalah kecocokan penggunaan produk (fitness for use) untuk memenuhi kebutuhan dan kepuasan pelanggan.

Sementara Nomi Pfeffer dan Coote berdasarkan hasil diskusi tentang mutu dalam jasa kesejahtraan sebagaimana dikutip Edward Sallis, ${ }^{10}$ mengemukakan bahwa "mutu merupakan konsep yang licin", mutu mengimplikasikan hal-hal yang berbeda pada masing-masing orang tak dapat dipungkiri bahwa setiap orang setuju terhadap upaya peningkatan mutu pendidikan. Hanya saja, masalah yang muncul kemudian adalah kurangnya kesamaan makna tentang mutu tersebut. Maka dari itu diperlukan pemahaman yang jelas terhadap variasi makna mutu tersebut, karena kalau tidak demikian, mutu hanya akan menjadi slogan belaka, sebuah kata bernada moral tinggi namun tidak memiliki nilai praktis.

Suatu produk dan/atau jasa dibuat sedemikian rupa agar dapat memenuhi kebutuhan dan harapan pelanggannya. Titik temunya antara harapan dan kebutuhan pelanggan dengan hasil produk dan/atau jasa itulah yang disebut "Bermutu". Jadi ukuran bermutu tidaknya suatu produk dan/atau jasa adalah pada terpenuhi tidaknya harapan dan kebutuhan pengguna/pelanggan. Semakin tinggi tuntutan pengguna maka semakin tinggi kualitas mutu tersebut. ${ }^{99}$ Sistem mutu dalam hal ini membutuhkan rangkaian umpan balik (feedback), yang bertujuan agar hasil akhir sebuah layanan bisa dianalisis menurut rencana. Memahami mutu pendidikan dapat dilihat berdasarkan kesamaan perspektif produsen dan konsumen. Peserta didik sebagai konsumen utama dalam pendidikan sudah seharusnya diutamakan dalam pengembangan mutu pendidikan. Namun terkadang dalam pelaksanaan pendidikan, seringkali kepentingan pengembangan kompetensi kurang menjadi perhatian. Akibatnya peserta didik harus mengalami berbagai perubahan sistem dan mutu pendidikan akibat pengaruh pihakpihak yang berkepentingan dan berkuasa atas pendidikan. Pemerintah pusat dan daerah

${ }^{7}$ Husaini Usman, Manajemen: Teori, Praktik dan Riset Pendidikan (Edisi Ketiga, Cet. 2; Jakarta; Bumi Aksara, 2010) h. 511.

${ }^{8}$ Umiarso \& Imam Gojali, Manajemen Mutu Sekolah di Era Otonomi Pendidikan: Menjual Mutu Pendidikan dengan Pendekatan Quality Control bagi Pelaku Lembaga Pendidikan (Cetakan II; Jogajakarta; IRCiSoD, 2011), h. 121.

${ }^{9}$ M. Nur Nasution, Manajemen Mutu Terpadu Manajemen Mutu Terpadu: Total Quality Management, Edisi Ketiga Cet. Pertama; Bogor; Ghalia Indonesia, 2015), h. 1.

${ }^{10}$ Edward Sallis, Manajemen Mutu Terpadu Pendidikan; Peran Strategi Pendidikan di Era Globalisasi Modern, terj. Ahmad Ali Riyadi dan Fachrurrozi (Yogyakarta, Ircisod, 2010), h. 49.

${ }^{11}$ Edward Sallis, Manajemen Mutu Terpadu Pendidikan; Peran Strategi Pendidikan di Era Globalisasi Modern, h. 27 
serta sekolah sebagai produsen pendi $\neg$ dikan selayaknya menerapkan sistem pendidikan profesional sehingga dapat membangun aliansi strategis antara kepentingan pendidikan, komersial dan politik pemerintah dalam pendidikan. Dengan mengadakan aliansi maka pendidikan akan memiliki sumber daya yang lebih mampu mengembangkan program pendidikan bermutu.

Upaya menjaga mutu pendidikan sulit dilepaskan keterkaitannya dengan manajemen mutu. Dalam manajemen mutu semua fungsi manajemen dijalankan oleh para kepala sekolah diarahkan agar semua pelayanan diberikan semaksimal mungkin sesuai atau melebihi harapan pelanggan. Berkaitan dengan upaya tersebut diperlukan upaya pengendalian mutu (quality control), oleh karena itu diperlukan upaya pengelolaan mutu dalam bentuk jaminan (assurance), bahwa semua aspek yang terkait dengan layanan pendidikan yang diberikan sekolah mencapai standar mutu tertentu disebut dengan istilah penjaminan mutu (quality assurance).

Berdasarkan beberapa pengertian dan dimensi mutu, maka dapat digambarkan bahwa mutu merupakan totalitas dari karakteristik suatu produk/jasa yang menunjang kemampuannya untuk memuaskan pelanggan. Atau dengan kata lain mutu secara umum dapat didefinisikan sebagai sebuah hasil terbaik yang dimiliki oleh seseorang atau sekelompok orang yang mampu memberikan kepuasan, kenyamanan, kesejahtraan yang berdampak terhadap minimnya keluhan dari pelanggan, tidak terkecuali di lembaga pendidikan.

\section{Teori-Teori Pakar tentang Mutu}

Total Quality Management difokuskan pada tiga pakar utama yang merupakan pionir dalam pengembangan TQM, Tiga tokoh penting tentang mutu adalah W. Edward Deming, Joseph Juran dan Philip B. Crosby. Ketiganya berkonsentrasi pada mutu dalam industri produksi, meskipun demikian ide-ide mereka juga dapat diterapkan dalam industri jasa seperti di bidang pendidikan. Meskipun dari ketiga tokoh mutu ini, tidak satupun dari mereka yang memberikan pertimbangan tentang isuisu mutu dalam pendidikan. Namun kontribusi mereka terhadap gerakan mutu begitu besar dan memang harus diakui bahwa eksplorasi mutu akan mengalami kesulitan tanpa merujuk pada pemikiran mereka. Ketiga teori pemikiran tersebut adalah:

\section{a. Metode W. Edward Deming}

W. Edward Deming menulis buku yang paling penting dengan judul Out of the Crisis, yang dipublikasikan pada tahun 1982. Buku ini menjelaskan tentang transformasi gaya manajemen Amerika di mana Deming mengkonsentrasikan penjelasannya pada kesalahan atau kegagalan manajemen untuk dijadikan dasar perencanaan di masa yang akan datang dan untuk meramalkan masalah yang akan terjadi. ${ }^{12}$ Deming secara spesifik melihat bahwa masalah mutu terletak pada masalah manajemen, khususnya kegagalan senior manajer dalam proses perencanaan. Deming mengemukakan hasil analisisnya mengenai kegagalan mutu, yang dibedakan menjadi dua, yaitu penyebab kegagalan khusus dan umum. Penyebab kegagalan umum adalah adanya kegagalan sistem, yaitu berkaitan dengan proses internal Lembaga. Deming secara tegas juga menekankan pentingnya pencegahan daripada memperbaiki kerusakan, hal inilah yang dinilai sebagai kontribusi unik dalam memahami bagaimana menjamin peningkatan mutu.

Sebagai ahli di bidang mutu, Deming mencatat kesuksesan dalam memimpin revolusi kualitas di Jepang yakni dengan memperkenalkan penggunaan teknis pemecahan masalah dan pengendalian proses statistic yang di kenal luas dengan statistical process control dan atas jasanya tersebut, maka setiap tahun diadakan penganugerahan penghargaan kepada setiap perusahaan yang berprestasi dalam hal kualitas, penghargaan ini dinamakan sesuai dengan namanya yakni Deming Prize yang

\footnotetext{
${ }^{12}$ Tim Dosen Administrasi Pendidikan UPI, Manajemen Pendidikan: Manajemen Peningkatan Mutu Pendidikan (Cetakan IV, Bandung; Penerbit Alfabeta, 2011), h. 293.
} 
merupakan penghargaan bergensi baik bagi individu yang berjasa dalam pengendalian kualitas dan metode statistika Jepang serta Deming Application Prize yang diberikan kepada perusahaan yang melaksanakan dengan baik pengendalian kualitas perusahaannya dan pengendalian mutu statistiknya. ${ }^{13}$ Deming menganjurkan penggunaan SPC agar perusahaan dapat membedakan penyebab sistematis dan penyebab khusus dalam menangani kualitas dengan keyakinan bahwa perbedaan atau variasi merupakan suatu fakta yang tidak dapat dihindari dalam kehidupan industri. Beberapa kontribusi yang membuat Deming terkenal, di antaranya:

Siklus Deming (Deming Cycle), Siklus ini dikembangkan untuk menghubungkan antara produksi suatu produk dengan kebutuhan pelanggan dan memfokuskan sumber daya semua bagian dalam perusahaan. Siklus ini adalah model perbaikan berkesinambungan yang dikembangkan oleh W Edward Deming yang terdiri atas empat komponen utama secara berurutan, seperti gambar berikut:

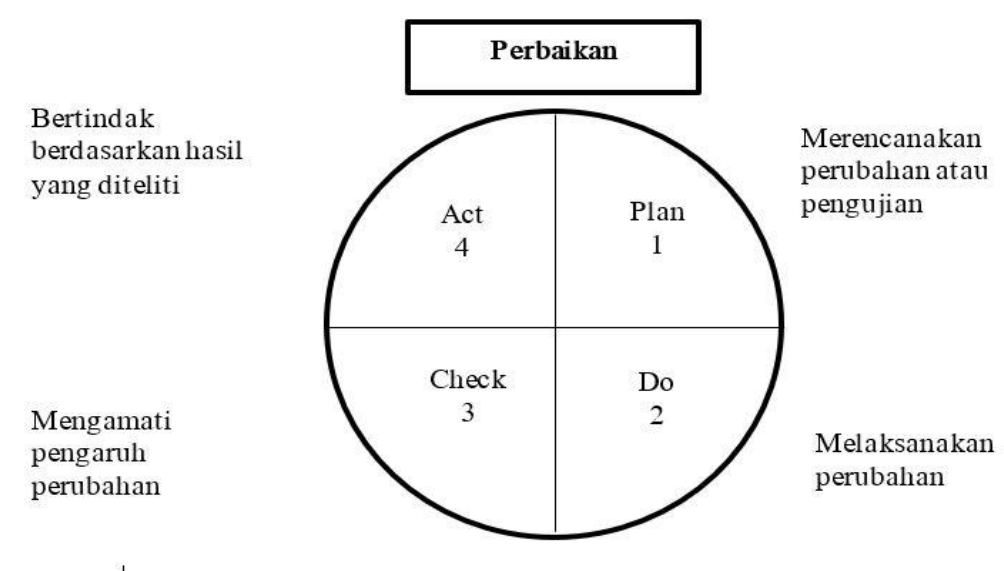

Gambar 2.2. Siklus PDCA (Plan-Do-Check-Act). ${ }^{14}$

Penerapan siklus PDCA (plan, do, check, and action) dan sebagian sarana yang menjamin terlaksananya secara terus menerus. Hal ini berguna dalam mewujudkan kebijakan untuk memelihara dan memperbaiki atau meningkatkan standar. Siklus ini merupakan konsep yang terpenting dari sebuah proses yang terdiri dari rencana (plan), berkaitan dengan penetapan target untuk perbaikan, dan perumusan rencana guna mencapai target, periksa (check) merujuk pada penetapan apakah penerapan tersebut berada pada jalur yang sesuai rencana dan memantau kemajuan perbaikan yang direncanakan, tindak (action) berkaitan dengan standarisasi prosedur baru guna menghindari terjadinya kembali masalah yang sama atau menetapkan sasaran baru.

\section{b. Metode Joseph M. Juran}

Seperti halnya Deming, Joseph M. Juran juga merupakan pelopor revolusi mutu Jepang. Dia juga lebih diperhatikan di Jepang dari pada di tempat kelahirannya, Amerika. Pada tahun 1981, kaisar Jepang memberikan anugerah bergengsi, Order of The Sacred Treasure. Juran terkenal karena keberhasilannya menciptakan "kesesuaian dengan tujuan dan manfaat". Ia dikenal sebagai "guru" manajemen pertama dalam menghadapi isu-isu manajemen mutu yang lebih luas. Sebagaimana Deming, Juran yakin bahwa kebanyakan masalah mutu dapat dikembalikan pada masalah keputusan manajemen.

\footnotetext{
${ }^{13}$ M. Nur Nasution, Manajemen Mutu Terpadu Manajemen Mutu Terpadu (Total Quality Management), h. 26.

${ }^{14}$ M. Nur Nasution, Manajemen Mutu Terpadu (Total Quality Management), h. 26.
} 
Kontribusi Juran terhadap pemikiran mutu yang paling terkenal antara lain: Juran's Three Basic Steps to Progress, Juran Ten Steps to Quality Improvement, The Pareto Principle, dan The Juran Trilogy. Untuk mengetahui lebih lanjut mengenai pemikiran Juran, maka selanjutnya akan diuraikan sebagai berikut:

a. Juran's Three Basic Steps to Progress

Menurut Juran dalam Fandi dan Anastasia, tiga langkah dasar merupakan langkah yang harus diambil perusahaan untuk mencapai kualitas tingkat dunia. Ketiga langkah tersebut, terdiri dari:

1. Mencapai perbaikan terstruktur atas dasar kesinambungan yang dikombinasikan dengan dedikasi dan keadaan yang mendesak;

2. Mengadakan program pelatihan secara luas;

3. Membentuk komitmen dan kepemimpinan pada tingkat manajemen lebih tinggi. ${ }^{15}$

b. Juran Ten Steps to Quality Improvement

Sepuluh langkah untuk memperbaiki kualitas menurut Juran dalam M.N. Nasution, sebagai berikut:

1. Membentuk kesadaran terhadap kebutuhan akan perbaikan dan peluang untuk melakukan perbaikan;

2. Menetapkan tujuan perbaikan;

3. Mengorganisasikan untuk mencapai tujuan yang telah ditetapkan;

4. Menyediakan pelatihan;

5. Melaksanakan proyek-proyek yang ditujukan untuk pemecahan masalah;

6. Melaporkan perkembangan;

7. Memberikan penghargaan;

8. Mengkomunikasikan hasil-hasil yang dicapai;

9. Menyimpan dan mempertahankan hasil yang dicapai;

10. Memelihara momentum dengan melakukan perbaikan dalam sistem regular perusahaan. ${ }^{16}$

\section{c. The Juran Trilogy}

The Juran Trilogy merupakan ringkasan dari tiga fungsi manajerial yang utama yakni perencanaan kualitas, pengendalian kualitas, perbaikan kualitas, adapun pandangan Juran terhadap fungsi-fungsi manajerial sebagaimana dikutip Fandi dan Anastasia, sebagai berikut: Selanjutnya Joseph M. Juran dalam Fandi dan Anastasia mengemukakan pandangan bahwa kepemimpinan yang mengarah kepada kualitas meliputi tiga fungsi manajerial, yaitu:

1. Perencanaan kualitas, fungsi ini meliputi langkah-langkah; identifikasi pelanggan, identifikasi kebutuhan pelanggan, mengembangkan produk berdasarkan kebutuhan pelanggan, mengembangkan metode dan proses kerja yang dapat menghasilkan produk yang memenuhi atau melampaui harapan pelanggan, dan mengubah hasil perencanaan ke dalam tindakan.

2. Pengendalian kualitas, fungsi ini mencakup langkah-langkah: evaluasi kinerja aktual, membandingkan kinerja aktual dengan tujuan, dan melakukan tindakan perbaikan untuk mengatasi perbedaan kinerja yang ada.

3. Perbaikan kualitas, fungsi ini terdiri atas langkah-langkah: membentuk infrastruktur untuk perbaikan kualitas secara berkesinambungan, identifikasi proses atau metode yang membutuhkan perbaikan, membentuk tim yang bertanggungjawab at as proyek perbaikan tertentu, dan menyediakan sumber daya serta pelatihan yang dibutuhkan tim perbaikan tersebut agar dapat mendiagnosis masalah dan mengidentifikasi penyebabnya, menemukan pemecahannya, dan melakukan perbaikan terhadap masalah tersebut. ${ }^{17}$

${ }^{15}$ M. N. Nasution, Manajemen Mutu Terpadu (Total Quality Management), h. 28-29.

${ }^{16}$ M. N. Nasution, Manajemen Mutu Terpadu (Total Quality Management), h. 29

${ }^{17}$ Fandi Tjiptono dan Anastasia Diana, Total Quality Management (TQM), h. 159-160 


\section{Pelaksanaan Quality Control Proses Pembelajaran Pada Pascasarjana Universitas Islam Negeri (UIN) Alauddin Makassar}

Dalam pengelolaan pendidikan, pimpinan lembaga pendidikan harus memperhatikan komponen-komponen di atas, selain itu harus mengevaluasi sejauh mana keberhasilan yang telah dilakukan yang berkaitan dengan teori yang dikemukakan oleh Juran yakni perencanaan kualitas (quality planning), pengendalian mutu (quality control), dan perbaikan serta peningkatan mutu (quality improvement).

\section{c. Metode Philip B. Crosby}

Philip B. Crosby adalah salah seorang pakar mutu yang selalu diasosiasikan dengan dua ide yang sangat menarik dan sangat kuat dalam mutu yakni anjuran manajemen Zero Defect "tanpa cacat" dan pencegahan, Crosby juga dikenal dengan Quality Vaccine dan Crosby's Fourteen Steps to Quality Improvement. Pandanganpandangan Philip B. Crosby dirangkumnya dalam ringkasan yang disebut sebagai dalildalil manajemen kualitas sebagaimana dikutip oleh M. N. Nasution, sebagai berikut:

Dalil pertama: Definisi kualitas adalah sama dengan persyaratan, Awalnya kualitas diterjemahkan sebagai tingkat kebagusan atau kebaikan (goodness), definisi ini memiliki kelemahan yakni tidak menerangkan secara sfesifik baik/bagus itu bagaimana. Hal ini tentunya tidak terlepas dari subjektivitas konsumen dalam menilai suatu produk maupun jasa.

Dalil kedua: Sistem kualitas adalah pencegahan, Pada masa lalu, sistem kualitas adalah penilaian (appraisal), misalnya, di pabrik TV diakhir proses baru dinyatakan apakah TV yang dihasilkan tergolong baik atau buruk, sehingga penilaian akhir ini hanya menyatakan bahwa apabila baik maka akan diserahkan kepada distributor, sebaliknya jika buruk akan disingkirkan.

Dalil ketiga: Kerusakan nol (zero defect) merupakan standar kinerja yang harus digunakan, Konsep yang berlaku di masa lalu, yaitu konsep mendekati (close enough concept), misalnya efisiensi mesin mendekati 95 persen. Namun, jika dihitung berapa besarnya inefisiensi 5 persen jika dikalikan dengan penjualan, oleh sebab itu Crosby mengajukan konsep kerusakan nol, yang mnenurutnya dapat tercapai bila institusi/perusahaan melakukan sesuatu secara benar semenjak pertama kali dan setiap kali.

Dalil keempat: ukuran kualitas adalah price of nonconformance, Kualitas harus merupakan sesuatu yang dapat diukur. Biaya untuk menghasilkan kualitas juga harus terukur. Menurut Crosby, biaya mutu merupakan penjumlahan antara biaya yang harus dikeluarkan karena melakukan kesalahan (price of nonconformance) dan biaya yang dikeluarkan bila tugas dilakukan secara benar semenjak pertama kali (price of conformance).

Pemikiran Philip B. Crosby, Crosby Quality Vaccine sebagaimana yang dikemukakan oleh Fandi dan Anastasia terdiri atas 3 unsur, yaitu determinasi, Pendidikan, dan pelaksanaan. Determinasi adalah suatu sikap dari manajemen untuk tidak menerima proses, produk atau jasa yang tidak memenuhi persyaratan, seperti reject, lead delivery, wrong shipment, dan lain-lain. Menurut Crosby, setiap perusahaan harus divaksinasi agar memiliki antibodi untuk melawan ketidaksesuaian terhadap persyaratan (nonconformance), ketidaksesuaian ini merupakan sebab, sehingga harus dicegah dan dihilangkan. Dalam menyiapkan vaksinasi, 5 (lima) unsur yang dibutuhkan, sebagai berikut:

1. Integritas,

CEO (chief executive office) harus dapat menjamin bahwa pelanggan menerima apa yang telah dijanjikan, seperti kualitas barang atau jasa, kualitas penyampaian, keamanan, dll. Dalam hal ini CEO harus memiliki pemikiran bahwa kualitas di atas segala-galanya

2. Sistem

Sistem adalah serangkaian prosedur dan kegiatan individu di dalam tim untuk menjamin kualitas. Untuk itu, diperlukan pendikan kualitas yang merupakan proses untuk membantu karyawan memiliki bahasa yang sama dan mengerti peran mereka dalam upaya peningkatan kualitas. 
3. Komunikasi

Dengan memiliki bahasa yang sama, maka komunikasi akan lebih mudah terjalin. Komunikasi yang dimaksud adalah proses mengirim dan menerima informasi mengenai kualitas dan mendukung peningkatan kualitas.

4. Operasi

Operasi adalah kegiatan sehari-hari yang dilakukan organisasi untuk menjaga agar tetap berfungsi. Hal ini dilaksanakan dengan mendidik pemasok agar mengirim produk dan jasa sesuai persyaratan.

5. Kebijaksanaan.

Dibutuhkan pula adanya pernyataan dan pengarahan dari manajemen yang memperjelas di mana mereka berdiri dan menentukan sikap tentang kualitas dalam hal ini kebijakan harus jelas dan tidak ragu-ragu.

Dengan mempelajari pemikiran dan teori mutu dari para pemikir mutu sebagaimana telah diuraikan sebelumnya, terdapat sejumlah persamaan antara ketiga pakar yakni W. Edward Deming, Joseph M. Juran, dan Philip B. Crosby, yakni sebagai berikut:

1. Inspeksi/pemeriksaan bukanlah jawaban atau kunci untuk melaksanakan perbaikan kualitas;

2. Keterlibatan dan kepemimpinan manajemen puncak sangat urgen dalam menciptakan budaya dan komitmen kualitas;

3. Program kualitas membutuhkan usaha dan pelibatan seluruh pihak dalam sebuah organisasi sekaligus merupakan bentuk komitmen jangka panjang.

4. Kualitas merupakan faktor utama (primer), sementara scheduling merupakan faktor sekunder. ${ }^{19}$

Para pemikir dan teori mutu sebagaimana yang telah dikemukakan oleh ketiga ahli tersebut, Baik W. Edward Deming maupun Joseph M. Juran memiliki konsentasi terhadap terhadap peningkatan mutu dalam bidang industri produk dengan pendekatan manajemen mutu terpadu, sementara ide yang dikemukakan oleh Philip B. Crosby menarik untuk diterapkan dalam dunia pendidikan di Indonesia karena beberapa factor, diantaranya: pertama, Konsep Zero Defect merupakan pemikiran yang menekankan pada upaya pencegahan di mana ide ini menjelaskan bahwa kesalahan, kegagalan, pemborosan, dan penundaan waktu, serta semua hal yang "tidak bermutu" lainnya dapat dihilangkan sejak awal jika lembaga dalam hal ini memiliki kemauan untuk itu, kedua, ide ini dapat didekati dengan menggunakan pendekatan sistem manajemen mutu khususnya lembaga pendidikan sebagaimana yang dikemukakan dalam teori Crosby Quality Vaccine dengan menerapkan pola pendekatan input, proses, dan output.

\section{B. Manajemen Mutu}

Istilah manajemen berasal dari bahasa latin, yakni dari asal kata manus yang berarti tangan dan agree yang berarti melakukan. Apabila kedua kata ini digabungkan maka menjadi kata kerja manager yang artinya menangani. Selanjutnya managere diterjemahkan ke dalam bahasa Inggris dalam bentuk kata kerja to manage, dengan kata benda management, dan manager untuk orang yang melakukan kegiatan manajemen. Akhirnya management diterjemahkan ke dalam bahasa Indonesia menjadi manajemen dan pengelolaan. ${ }^{20}$ Dalam Kamus Inggris-Indonesia karya Jhon M. Echols

\footnotetext{
${ }^{18}$ Fandi dan Anastasia, Total Quality Management (TQM), h. 58-59

${ }^{19}$ M. N. Nasution, Manajemen Mutu Terpadu (Total Quality Management), h.33.

${ }^{20}$ Husaini Usman, Manajemen: Teori, Praktik dan Riset Pendidikan, h. 3.
} 


\section{Pelaksanaan Quality Control Proses Pembelajaran Pada Pascasarjana Universitas Islam Negeri (UIN) Alauddin Makassar}

dan Hassan Shadily memaknai manajemen (management) sebagai direksi, pimpinan, ketatalaksanaan, tata pimpinan dan pengelolaan. ${ }^{21}$

Selanjutnya dalam Websters Dictionary karya John Gage Allee, mengemukakan bahwa management berasal dari bahasa Inggris yakni:

Management yang berarti to direct, to control, to carry on, to cope with, to direct affairs, to seccred. Jadi manajement berarti the act of managing, administration, body of directors controlling, bussiness. ${ }^{22}$

Hal ini dapat dimaknai bahwa manajemen mengandung arti kepemimpinan, pengontrolan atau sesuatu yang bertalian dengan masalah pengontrolan administrasi yang awalnya diterapkan dalam dunia bisnis/industri. Selanjutnya definisi yang dikemukakan para ahli tentang manajemen, misalnya Robert Kreitener memberikan rumusan manajemen yang menyatakan bahwa:

Management is the process of working and trough others to achieve organizational objektives in a changing environment central to this process is the effective and efficient use of limited resources. ${ }^{23}$

Secara bebas dapat dimaknai bahwa manajemen adalah proses bekerja dengan dan melalui orang lain untuk mencapai tujuan organisasi dalam lingkungan yang berubah dan proses ini berpusat pada penggunaan secara efektif dan efesien terhadap sumber daya yang terbatas. Pelbagai pengertian manajemen oleh para ahli di bidang manajemen, di antaranya menurut George R. Terry yang merumuskan proses pelaksanaan manajemen terdiri dari mpat hal penting, yakni planning, organizing, actuating, dan controlling. ${ }^{24}$

Selanjutnya George R. Terry dan L.W. Rue merumuskan bahwa manajemen adalah suatu proses atau kerangka kerja, yang melibatkan bimbingan atau mengarahkan suatu kelompok orang-orang ke arah tujuan-tujuan organisasional atau maksud-maksud yang nyata. ${ }^{25}$ Dari beberapa pendapat ahli mengenai manajemen, dapat dipahami bahwa manajemen merupakan suatu proses yang berjalan terus pada suatu arah perbaikan dengan melibatkan berbagai sumber untuk pencapaian tujuan, baik itu sumber daya manusia maupun sumber daya alam perlu diperhatikan pemanfaatannya secara optimal dalam mencapai suatu tujuan.

Sejalan dengan Azhar Arsyad, yang mengemukakan bahwa manajemen membahas tentang bagaimana para manajer berusaha agar sesuatu terkerjakan dengan baik (bersama dengan atau oleh orang lain). Bila dikaitkan dengan "politik dan kekuasaan dalam suatu organisasi", itu berarti bagaimana menerapkan kekuasaan agar orang lain sudi melakukan sesuatu. Itu juga berarti bagaimana menerapkan kekuasaan agar orang lain terpengaruh melalukan sesuatu. ${ }^{26}$ Oleh sebab itulah, manajemen menjadi sangat penting artinya dari segala aspek kehidupan, karena itu manajemen menjadi ikon yang urgen baik secara individual maupun secara kelompok.

\footnotetext{
${ }^{21}$ Jhon M. Echols dan Hassan Shadily, Kamus Inggris-Indonesia (Jakarta: PT. Gramedia 2005), h. 372 . 228.

${ }^{22}$ John Gage Allee, Websters Dictionary (Chicago, Wilcox \& Folt Book Company, 2003), h.

${ }^{23}$ Robert Kritiner, Management (4th Edition; Boston: Houghton Mifflin Company, 2009), h. 9.

${ }^{24}$ Controlling (pengawasan) yang biasa diartikan dengan pengendalian yang memberi arti mencek dan mengarahkan tindakan begitu pekerjaan dimulai untuk menerapkan rencana. Lihat John Andair sebagaimana dikutif oleh John Salindeho, Peranan Tindak Lanjut dalam Manajemen (Cet. II; Jakarta: Sinar Grafika, 2009), h. 34.

${ }^{25}$ George R. Terry, Principle of Management (6th Edition; Georgetown: Richard D. Irwing Inc., 2002), h. 2.

${ }^{26}$ Azhar Arsyad, Pokok Pokok Manajemen: Pengetahuan Praktis bagi Pimpinan dan Eksekutif (Yogyakarta, Cetakan III, Pustaka Pelajar Offset), h. 1.
} 
Pengertian manajemen atau seringkali disebut pula "pengelolaan" merupakan kata yang digunakan sehari-hari, sehingga diandaikan semua orang tahu artinya. Definisi sesungguhnya kata tersebut ternyata banyak sekali, tergantung pada cara pandang, kepercayaan, atau pengertian seseorang. Pada dasarnya ajaran Islam yang tertuang dalam al-Qur'ān dan al-Sunnah, maupun ijma' ulama banyak mengajarkan tentang kehidupan yang serba terarah dan teratur. Dalam pelaksanaan shalat yang menjadi ikon paling sakral dalam Islam merupakan contoh kongkrit adanya manajemen yang mengarah kepada keteraturan. Puasa, haji dan amaliyah lainnya merupakan pelaksanaan manajemen yang monumental.

Keteraturan alam raya ini merupakan bukti kebesaran Allah swt dalam mengelola alam ini. Namun, karena manusia yang diciptakan Allah swt., sebagai khalifah di bumi, maka manusia harus mengatur dan mengelola bumi dengan sebaikbaiknya sebagaimana Allah mengatur alam raya ini. Dengan demikian manajemen merupakan komponen integral dan tidak dapat dipisahkan dari segala proses dan aktifitas kehidupan manusia, terutama dalam menata dan mengelola kehidupan ke arah yang lebih baik dan berkualitas.

\section{Manajemen dalam Perspektif Islam}

Teori dan konsep manajemen yang digunakan saat ini sebenarnya bukan hal yang baru dalam perspektif Islam. Namun, bila didekati dari istilah bahasa Arab dapat dikemukakan disini bahwa kata "yudabbiru" diartikan mengarahkan, mengelola, melaksanakan, menjalankan, mengatur atau mengurusi. Hal ini menggambarkan bahwa Allah swt., yang mengatur segala urusan. Keberadaan Allah sebagai Maha Pencipta dihubungkan dengan penciptaan alam, langit dan bumi serta segala isinya sehingga segala urusan yang ada di alam semesta ini adalah Allah yang Maha Mengetahui, mengawasi dan memeliharanya. Demikian juga halnya dengan konsep manajemen dalam perspektif Islam yang bermakna pengaturan, berdasarkan firman Allah swt., dalam QS al-Sajadah/32: 5.

Dari isi kandungan ayat di atas ditegaskan bahwa Allah swt., adalah pengatur alam (manager), Selanjutnya kaitannya dengan ayat di atas, Abuddin Nata mengemukakan beberapa hal yang menarik untuk dicapai sebagai berikut: pertama, adanya kata yudabbiru yang berarti mengatur, mengurus dan me-manage, mengarahkan, membina, merencanakan, melaksanakan, dan mengawasi; kedua, adanya objek atau berbagai hal yang diatur, diurus, dibina dan seterusnya termasuk didalamnya pengaturan siang dan malam yang mengacu pada pengaturan waktu untuk melakukan pekerjaan. ketiga, adanya unsur yang mengatur, mengelola dan seterusnya dalam hal ini adalah Tuhan. Dengan demikian, Tuhan telah menampilkan dirinya sebagai administrasi atau manajer yang andal dan sebagai administrator, Tuhan memiliki berbagai kompetensi yang luar biasa. ${ }^{27}$

Ilmu manajemen telah berkembang sebagai fenomena kehidupan modern menyertai kehadiran berbagai organisasi di masyarakat. Di dalamnya dimaksudkan untuk pengelolaan kegiatan manusia dalam memenuhi kebutuhan hidupnya secara bersama, perilaku bekerjasama sebagai sesuatu yang bersifat fitrah didasarkan pada prinsip tauhid, khalifah dan amanah ${ }^{28}$.

1) Tauhid

Tauhid menempatkan manusia pada kedudukan tertentu sejak dari etika niat sebagai awal dari pemenuhan tuntutan dalam ketika tindakan, apapun usaha dan tindakan manusia harus sesuai dengan kehendak Allah swt., dengan keikhlasan dan ketauhidan. Setiap tindakan dan usaha manusia, apalagi yang terkait dengan ibadah mahdah, tidak boleh bertentangan dengan keesaan Allah.

\footnotetext{
${ }^{27}$ Abuddin Nata, Pendidikan dalam Persfektif Al-Qur'an, h. 266-267.

${ }^{28}$ Syafaruddin. Manajemen Lembaga Pendidikan Islam, h. 187
} 


\section{Pelaksanaan Quality Control Proses Pembelajaran Pada Pascasarjana Universitas Islam Negeri (UIN) Alauddin Makassar}

Pengaturan urusan yang ada di alam ini benar-benar berdimensi tauhid, atau mengakar pada tindakan pengesaan Allah swt., sebagaimana firman-Nya dalam QS Yunus/10: 3 .

Menurut al-Faruqi sebagaimana yang dikutip oleh Syafaruddin menjelaskan bahwa prinsip tauhid harus menjadi pondasi bagi seluruh prilaku individu dan kelompok dalam membangun kebudayaannya. Kesucian niat untuk mencari keridhaan dan menuju keesaan Allah menjadi inti dari perilaku manajerial manusia sebagai khalifatullah di bumi ini. Potensi manusia untuk memperoleh pengetahuan menjadi kualitas tersendiri yang tidak dimiliki oleh makhluk lain, sehingga hanya manusia yang memiliki kebebasan moral untuk memenuhi dan mematuhi kehendak Allah swt., dalam mengelola, mengatur dan mengurus segala kegiatan memakmurkan alam ini.

2) Khalifah

Kekhalifahan manusia, amanah, serta ibadah menjadi dasar konseptual manajemen Islami yang akan dikembangkan dengan mengintegrasikan atau mengakomodasi pemikiran manajemen modern. Karena bagaimanapun, pemikiranpemikiran manusia sepanjang sejarahnya tidak seluruhnya bertentangan dengan nilainilai kewahyuan. Manajemen Islami adalah konsep pengurusan atau pengelolaan organisasi atau kegiatan tertentu untuk mencapai tujuan yang sesuai dengan pencapaian kebaikan, keselamatan dan kesejahteraan umat manusia baik di dunia maupun di akhirat.

Allah swt., menciptakan manusia sebagai makhluk terbaik ciptaan-Nya, berarti ketaatan dan kepatuhan manusia kepada Allah merupakan alasan penciptaan manusia. Karena itu kekhalifahan manusia di bumi juga merupakan tujuan penciptaan manusia, dan sekaligus hanya manusia yang mau dan mampu menerima amanat dari Allah dengan etika religius bahwa manusia bebas memilih dan berkehendak untuk mengikuti perintah-perintah Allah. Untuk memperoleh tindakan dari anggota yang dipimpin, maka seorang pemimpin harus menunjukkan keteladanan. Sehubungan dengan hal itu Allah swt., berfirman dalam QS al-Baqarah/2: 44.

Bertolak dari konsep tauhid, khalifah dan amanah, perlu dibangun suatu paradigma manajemen Islami untuk dikembangkan oleh para manajer muslim dan berbagai organisasi baik perusahaan, industri, bisnis maupun lembaga pendidikan untuk menjadi kerangka dasar konseptual dalam melahirkan atau membangun dasardasar manajemen Islami. Di samping itu, dalam menempatkan seseorang dalam suatu tugas dan tanggung jawab, tidak boleh memberikan kepercayaan dan tanggung jawab tugas melebihi kemampuan seseorang, hal inilah menjadi dasar dalam menerapkan konsep dan prinsip manajemen yang baik,

Dalam perspektif Islam, manajemen dalam kehidupan baik secara individu maupun bermasyarakat memiliki 3 (tiga) hal yang menjadi prinsip dalam pelaksanaannya dalam kehidupan sehari-hari yakni; 1. Bagaimana seorang individu dapat mengelola waktu secara baik, 2. Bagaimana seorang individu dapat bekerja secara baik dan profesional, dan 3. Bagaimana seorang individu dapat beribadah secara baik dan konsisten. Hal inilah yang menjadi aspek terpenting dalam mewujudkan kehidupan yang dapat mendukung upaya peningkatan kualitas sumber daya manusia sebab kemajuan suatu bangsa sangat dipengaruhi oleh sumber daya manusia yang dimiliki oleh bangsa tersebut. Demikian juga halnya dengan kualitas sumber daya manusia sangat tergantung pada tingkat pendidikan masing-masing. Dalam hal ini, pendidikan yang visioner harus memiliki visi dan misi yang jelas yang nanti diharapkan dapat menghasilkan luaran yang berkualitas.

\section{Manajemen Mutu dalam Pendidikan}

Manajemen atau seringkali disebut pula pengelolaan merupakan kata yang digunakan sehari-hari, Definisi manajemen sangat banyak tergantung pada cara pandang, kepercayaan, atau pengertian seseorang. Indrajit dan Djokopranoto, manajemen adalah sebuah proses yang terjadi dalam aktivitas manajemen yaitu perencanaan, pengorganisasian, penggerakan dan pengawasan atau sering pula disebut fungsi manajemen. Manajemen dalam arti luas adalah perencanaan, pengorganisasian, 
pengarahan dan pengendalian (4P) sumber daya organisasi untuk mencapai tujuan secara efektif dan efisien.

Usman menjelaskan bahwa, manajemen pendidikan adalah seni dan ilmu mengelola sumber daya pendidikan untuk mewujudkan suasana belajar dan proses pembelajaran agar peserta didik secara aktif mengembangkan potensi dirinya untuk memiliki kekuatan spiritual keagamaan, pengendalian diri, kepribadian, kecerdasan, akhlak mulia, serta keterampilan yang diperlukan dirinya, masyarakat bangsa dan Negara. ${ }^{29}$ Siswanto berpendapat bahwa manajemen adalah ilmu dan seni untuk melakukan tindakan guna mencapai tujuan. Manajemen sebagai suatu ilmu adalah akumulasi penetahuan yang disistematisasikan atau kesatuan pengetahuan yang terorganisasi. ${ }^{30}$ Dari beberapa Definisi di atas dapat disimpulkan bahwa pengertian manajemen adalah suatu proses kerjasama atau kegiatan yang terdapat fungsi manajemen yaitu perencanaan, pengorganisasian, pelaksanaan, dan pengevaluasian dengan melibatkan sumber-sumber, baik manusia maupun non-manusia untuk mencapai tujuan yang efektif dan efisien.

Arah baru kebijakan pendidikan saat ini adalah berorientasi pada mutu, orientasi terhadap mutu ini pada dasarnya merupakan adopsi dari dunia bisnis. Sebagaimana yang dikemukakan oleh Syafaruddin bahwa Manajemen Mutu Terpadu (Total Quality Management) merupakan salah satu strategi manajemen untuk menjawab tantangan eksternal suatu organisasi guna memenuhi kepuasan pelanggan. ${ }^{31}$ Dalam aplikasinya, istilah mutu terhadap pendidikan disebut pula Total Quality Education (TQE). Dalam konteks aplikasi konsep manajemen mutu terpadu terhadap Pendidikan. Manajemen mutu terpadu menekankan pada dua konsep utama. Pertama, sebagai suatu filosofi dari perbaikan terus menerus (continous improvement), dan yang kedua berhubungan dengan alat-alat dan teknik seperti brainstorming dan force field analysis (analisis kekuatan lapangan) yang digunakan untuk perbaikan kualitas dalam tindakan manajemen untuk mencapai kebutuhan dan harapan pelanggan.

\section{METODOLOGI PENELITIAN}

Penelitian yang digunakan adalah penelitian kualitatif. Penelitian ini termasuk katagori penelitian yang bersifat kualitatif deskriptif, karena penelitian ini memberi gambaran tentang hasil penelitian yang mendeskripsikan data-data aktual yang diperoleh di lapangan.

Penelitian ini dilaksanakan di Universitas Islam Negeri Alauddin Makassar yang beralamat di jalan H. M. Yasin Limpo No. 36 Samata-Gowa. Pemilihan lokasi penelitian ini didasarkan pada pendapat Lexy J. Moleong yang mengatakan bahwa salah satu faktor yang perlu dijadikan pertimbangan dalam menentukan lokasi penelitian adalah faktor waktu dan kelancaran transportasi dari lokasi penelitian, sehingga memudahkan peneliti dalam melaksanakan proses penelitian.

Pendekatan penelitian yang digunakan yaitu; pendekatan metodologis (fenomenologi), dan pendekatan keilmuwan (pedagogis, psikologis dan sosiologis).

Pada penelitian kualitatif, sampel data sumber dapat bersifat purposive sampling. Dalam penelitian ini, ada dua jenis sumber data yaitu sumber data primer dan sekunder. Data primer adalah data utama yang peneliti peroleh secara langsung di lapangan yakni pengambilan data secara langsung dengan pihak-pihak yang terkait dengan masalah yang akan diteliti, ${ }^{32}$ terdiri atas unsur peserta didik dalam hal ini

\footnotetext{
${ }^{29}$ Husaini Usman, Manajemen; Teori, Praktik dan Riset Pendidikan, h. 12.

${ }^{30}$ Siswanto. Pengantar Manajemen (Jakarta. Penerbit Bumi Aksara, 2007), h. 7

${ }^{31}$ Syafaruddin. Manajemen Mutu Terpadu dalam Pendidikan; Konsep, Strategi, dan Aplikasi, h.

${ }^{32}$ Moh. Kasiram, Metodologi Penelitian Kualittatif-Kuantitatif (Malang; UIN Malang Press,
} 2008) h. 231. 
mahasiswa, dosen, direktur, wakil direktur, dan ketua program studi serta pegawai yang dijadikan informan melalui wawancara secara langsung dengan menggunakan teknik wawancara tidak terstruktur, Sedang data sekunder adalah data pendukung atau data yang diperoleh secara tidak langsung atau penunjang apabila dibutuhkan. Data sekunder diperoleh dari dokumen-dokumen seperti dokumen kurikulum, dokumen pembelajaran, data-data dosen dan mahasiswa, serta berbagai foto kegiatan pembelajaran. Selain itu data juga diperoleh melalui berbagai referensi dari literatur, baik itu berupa laporan, artikel maupun dokumen-dokumen, baik yang bersumber dari buku-buku, artikel lain yang memiliki relevansi dan substansi dengan penelitian yang dilakukan. Metode pengumpulan data pada penelitian ini adalah observasi, wawancara, dan dokumentasi.

Uji keabsahan data dalam penelitian kualitatif menurut Sugiyono adalah meliputi credibility (validitas internal), transferability (validitas eksternal), dependability (reliability), dan confirmability (objektivitas).

\section{HASIL PENELITIAN DAN PEMBAHASAN}

\section{A. Quality control pada aspek proses pembelajaran di Pascasarjana Universitas Islam Negeri Alauddin Makassar.}

Pelaksanaan qualiti control pada aspek proses pembelajaran dibagi menjadi tiga yaitu perencanaan pembelajaran, pelaksanaan pembelajaran, evaluasi hasil pembelajaran, sebagai berikut:

Sistem pembelajaran disusun berdasarkan perencanaan yang relevan dengan tujuan, ranah (domain) belajar dan hierarkinya. Kegiatan pembelajaran adalah pengalaman belajar yang diperoleh pebelajar dari kegiatan belajar, seperti perkuliahan (tatap muka atau jarak jauh), praktikum atau praktek, magang, pelatihan, diskusi, lokakarya, seminar, dan tugas-tugas pembelajaran lainnya. Dalam pelaksanaan pembelajaran digunakan berbagai pendekatan, strategi, dan teknik, yang menantang agar dapat mengkondisikan pebelajar berpikir kritis, bereksplorasi, berkreasi, dan bereksperimen dengan memanfaatkan aneka sumber belajar.

Strategi pembelajaran memperhitungkan karakteristik pebelajar termasuk kemampuan awal yang beragam yang memungkinkan dosen menerapkan strategi yang berbeda. Dalam mengaplikasikan strategi pembelajaran dosen mendasarkan pada konsep bahwa setiap orang memiliki potensi untuk berkembang secara akademik dan profesional.

Sistem pembelajaran mencakup pemantauan, pengkajian, dan perbaikan secara berkelanjutan. Kajian dan penilaian atas strategi pembelajaran yang digunakan dilakukan melalui perbandingan dengan strategi-strategi pembelajaran terkini. Perkuliahan selama ini diatur oleh bagian administrasi dan akademik (pengaturan jadwal, pengaturan ruangan, penyediaan absen dan penetapan dosen penanggung jawab mata kuliah).

Pelaksanaan perkuliahan selama ini dilakukan dengan memadukan kurikulum yang telah dirancang. Kegiatan pembelajaran dilaksakan dengan mengacu pada kalender akademik yang dikeluarkan pihak universitas dimana kalender akademik disusun dalam satu tahun ajaran, dimana kalender akademik ini merupakan acuan dalam penyelenggaran pendidikan dan pengajaran dalam satu tahun akademik.

\section{a. Perencanaan Pembelajaran}

Dalam pelaksanaan proses pembelajaran harus memiliki mekanisme yang sistematis dan terstruktur dengan baik, agar proses belajar mengajar dapat berjalan dengan baik. Berdasarkan observasi yang penulis lakukan dimana sebelum kegiatan proses belajar mengajar berlangsung telah disusun dan tersedia namun belum disosialisasikan secara umum, sehingga tidak semua staheholder mengetahui jadwal, menurut peneliti idealnya kalender akademik harus disosialisasikan baik melalui website maupun pada papan pengumuman dapat diakses oleh mahasiswa maupun 
dosen sehingga mereka mengetahui dengan jelas semua proses baik kegiatan akademik maupun administrasi selama satu tahun akademik yang akan berjalan.

Di Pascasarjana UIN Alauddin Makassar, saat ini distribusi KRS telah diberikan dengan sistem paket yakni mahasiswa menjalani perkuliahan yang diberikan berdasarkan mata kuliah yang telah ditentukan berdasarkan kurikulum yang ada dengan menggunakan sistem yang dikenal dengan nama sistem informasi akademik dan kemahasiswaan (disingkat dengan nama SIAKAD).

Sebelum proses pembelajaran dilakukan terlebih dahulu seluruh mahasiswa yang telah memenuhi persyaratan untuk mengikuti perkuliahan akan verifikasi pada bagian akademik sebagai dasar untuk menyusun jadwal dan daftar mata kuliah yang akan diprogramkan pada semester tersebut, kemudian menyusun jadwal kuliah dan penetapan dosen mata kuliah pengampuh. Daftar dosen pengampuh mata kuliah dan jadwal mata kuliah yang telah disusun akan diumumkan kepada seluruh mahasiswa yang buat oleh bagian akademik, setelah itu bagian akademik akan menyiapkan daftar hadir untuk mahasiswa dan dosen. Selanjutnya jadwal tersebut disinkronkan dengan sistem dalam rangka pelaporan pada Pangkalan Data Perguruan Tinggi (PD-Dikti).

Sebelum perkuliahan dimulai, tentunya yang harus dilakukan adalah membuat sistem dan prosedur perencanaan pembelajaran dan siapa yang bertanggung jawab dalam perencanaan pembelajaran tersebut, berikut hasil wawancara dengan direktur mengenai perencanaan pembelajaran:

Dalam kegiatan akademik, perencanaan menjadi sesuatu yang sangat penting oleh sebab itu setiap awal tahun ajaran baru rutin dilaksanakan rapat edukasi dengan para dosen, hal ini dilakukan untuk mengevaluasi pembelajaran yang telah dilaksanakan dan menyusun strategi dalam mensukseskan program yang selanjutnya, selain itu rapat-rapat internal terkait hal tersebut juga dilakukan untuk membahas mengenai mekanisme dan pendelegasian penugasan kepada seluruh staf diPascasarjana yang bertujuan untuk mendukung kegiatan pembelajaran agar terlaksana dengan baik. ${ }^{3}$

Terkait dengan perencanaan pembalajaran yang selama ini dilakukan di Pascasarjana, hal senada juga diungkapkan oleh wakil direktur bidang akademik bahwa:

Sebelum perkuliahan dimulai maka perlu dilakukan sebuah perencanaan dengan tahapan yang dimulai dengan bagian administrasi akademik dengan membuat jadwal perkuliahan, bagian data melakukan penginputan KRS pada sistem administrasi akademik, staf pada masing-masing prodi membuat daftar hadir/absensi, yang tidak kalah pentingnya adalah penyampaian dan jadwal dan kesiapan dosen untuk melaksanakan pengajaran dan tersedianya sarana prasarana pembelajaran yang biasanya dikontrol langsung oleh pimpinan melalui pelaksana tata usaha Pascasarjana. Hal lain yang selalu dilaksanakan selama ini adalah melaksanakan rapat-rapat edukasi pada awal tahun ajaran, hal ini dilakukan untuk mengevaluasi pembelajaran yang telah dilaksanakan dan menyusun strategi dalam menyukseskan program dalam hal ini yang berkaitan dengan kegiatan akademik.

Untuk mendapat informasi yang lebih detail mengenai hal tersebut, peneliti melakukan wawancara dengan sumber lain sekaligus menjadi triangulator yakni dengan Ketua Komite Penjaminan Mutu Pascasarjana UIN Alauddin Makassar perihal perencanaan pembelajaran yang dilaksanakan, mengemukakan bahwa:

Selama ini, bagian administrasi dan akademik betanggung jawab atas seluruh kelengkapan pelaksanaan perkuliahan termasuk absensi kehadiran mahasiswa

${ }^{33}$ Sabri Samin, Direktur Pascasarjana UIN Alauddin Makassar, Wawancara, Gowa, 29 Desember 2017.

${ }^{34}$ Achmad Abubakar, Wakil Direktur bidang Akademik Pascasarjana UIN Alauddin Makassar, Wawancara, Gowa, 5 Nopember 2017. 


\section{Pelaksanaan Quality Control Proses Pembelajaran Pada Pascasarjana Universitas Islam Negeri (UIN) Alauddin Makassar}

yang disusun berdasarkan semester, mata kuliah, kelas, jam dan ruangan untuk absensi manual dan sebagai pengelola penjaminan mutu, seringkali saya terlibat langsung untuk membantu menangani hal-hal tersebut secara teknis seperti pendistribusian dosen pengampu matakuliah. ${ }^{35}$

Berdasarkan hasil wawancara dengan informan di atas, diketahui bahwa perencanaan pembelajaran sudah dilakukan dan sesuai dengan prosedur yang telah ditetapkan dan yang bertanggungjawab terhadap perencanaan pembelajaran tersebut adalah bagian administrasi akademik.

Proses perencanaan pembelajaran di Pascasarjana UIN Alauddin Makassar dapat berjalan dengan baik. Persiapan Absensi khususnya absensi mahasiswa sebelum perkuliahan dimulai sangat penting dimana, absen ini merupakan alat kontrol baik oleh dosen, ketua program studi maupun bagian administrasi akademik untuk melihat mengetahui jumlah mahasiswa yang memprogramkan mata kuliah, sehingga dengan absensi tersebut dapat dilakukan pengendalian terhadap tingkat kehadiran dan tatap muka sebagaimana yang telah ditetapkan dalam aturan akademik.

\section{b. Pelaksanaan Pembelajaran}

Pelaksanaan kegiatan pembelajaran tidak hanya dilihat dari pesentase kehadiran mahasiswa namun juga yang perlu diperhatikan adalah kehadiran dosen itu sendiri dalam proses kegiatan belajar mengajar, dalam proses pembelajaran kehadiran dosen dalam kelas sangat berpengaruh pada kualitas proses pembelajaran itu sendiri, dimana dengan tingkat kehadiran dosen di dalam kelas harus berbanding lurus dengan persentase kehadiran mahasiswa. Untuk mengetahui gambaran proses pembelajaran yang berjalan selama ini, maka peneliti melakukan wawancara dengan ketua Direktur Pascasarjana UIN Alauddin Makassar, berikut petikan hasil wawancaranya:

“...proses pembelajaran selama ini berjalan dengan sesuai dengan yang direncanakan dimana setiap dosen yang masuk mengajar mengisi daftar hadir yang telah disiapkan yang terdiri dari pertemuan, tanggal dan materi yang diajarkan tiap pertemuan. Hal juga dapat dilihat pada absensi mahasiswa dan dosen". 36

Tingkat kehadiran dosen dalam mengajar di kelas merupakan salah satu tolok ukur berhasil tidaknya sebuah proses pembelajaran, berdasarkan hasil wawancara dengan wakil direktur bidang akademik yang biasa mengontrol proses belajar mengajar, berikut hasil wawancaranya:

Proses pembelajaran selama ini berjalan baik materi kuliah dosen pada setiap pertemuan dalam proses pembelajaran tercantum dengan jelas pada absensi dosen mulai dari pokok bahasan sub pokok bahasan dan pemberian tugas kuliah kepada mahasiswa dengan rata-rata tingkat kehadiran dosen di atas 90\%. Materi perkuliahan disusun oleh dosen masing-masing dengan tetap mengacu pada Rencana Program Semester (RPS) dan Satuan Acara Perkuliahan (SAP) yang disusun oleh perguruan tinggi maupun yang disusun oleh dosen yang bersangkutan. proses mengajar dilaksanakan sebanyak 16 kali pertemuan termasuk ujian akhir semester.

Pengawasan pembelajaran dilakukan pada saat proses kegiatan belajar mengajar berlangsung. Berdasarkan hasil wawancara dengan Wakil Direktur tentang pelaksanaan pengawasan pembelajaran, berikut hasil petikan wawancaranya:

${ }^{35}$ Firdaus, Ketua Komite Penjaminan Mutu Pascasarjana UIN Alauddin Makassar, Wawancara, Gowa, 10 Nopember 2017.

${ }^{36}$ Sabri Samin, Direktur Pascasarjana UIN Alauddin Makassar, Wawancara, Gowa, 29 Desember 2017.

${ }^{37}$ Achmad Abubakar, Wakil Direktur bidang Akademik Pascasarjana UIN Alauddin Makassar, Wawancara, Gowa, 5 Nopember 2017. 
Pengawasan yang dilakukan selama ini dalam proses pembelajaran adalah dengan melakukan evaluasi setiap kegiatan pembelajaran yang dilakukan baik yang berhubungan dengan mahasiswa maupun dosen, pengawasan yang dilakukan selama ini lebih difokuskan pada tersedianya seluruh perangkat pembelajaran yang mendukung proses belajar mengajar terutama pada sarana dan prasarana yang ada. Sedangkan pada proses pembelajaran lebih ditekankan pada materi yang diajarkan oleh dosen setiap pertemuan yang dikontrol melalui absensi dosen, dan kuisioner Course Evaluation Survey (CES) yang bagikan untuk setiap mahasiswa untuk mengevaluasi kegiatan belajar mengajar.

Pengawasan tidak hanya dilakukan pada saat proses perkuliahan telah selesai namun pengawasan ini harus terus menerus dilakukan mulai pada saat perencanaan kegiatan perkuliahan sampai selesainya proses perkuliahan atau akhir semester, hal ini untuk menjamin bahwa semua proses belajar berjalan dengan baik. Proses belajar mengajar selama ini berjalan dengan baik, karena semua kegiatan proses belajar mengajar mengajar telah terjadwal dengan baik dan dosen mengajar sesuai dengan jadwal yang telah ditentukan dan materi yang berikan kepada mahasiswa sesuai dengan rencana program pembelajaran yang telah disusun yang ditunjang dengan pemberian tugas-tugas berupa tugas individu maupun secara berkelompok dalam membuat karya tulis untuk dipresentasikan di kelas untuk setiap mata kuliah.

\section{c. Evaluasi Hasil Pembelajaran}

Setelah kegiatan proses belajar mengajar dilaksanakan, maka kegiatan selanjutnya adalah evaluasi pembelajaran atau penilaian hasil pembelajaran. Pelaksanaan ujian dilakukan secara serentak oleh panitia pelaksana Ujian Akhir Semester (UAS). sebelum pelaksanaan ujian akhir semester, bagian administrasi akademik mengirimkan surat permintaan kepada setiap dosen pengampu mata kuliah untuk memasukkan naskah soal yang akan diujikan kepada mahasiswa.

Hal ini dilaksanakan selain untuk memberikan bekal yang lebih kepada mahasiswa dengan memperbanyak belajar, hal lainnya yakni diharapkan dengan pelaksanaan ujian secara serentak juga dosen diharapkan akan memasukkan nilai hasil ujian sesuai dengan jadwal yang telah ditentukan, dengan demikian kegiatan ujian sampai pada proses pemberian nilai hasil ujian mahasiswa telah terjadwal dengan baik dan hal itu harus diikuti oleh mahasiswa maupun dosen.

Hal senada juga di kemukakan oleh Wakil Direktur bidang akademik, berikut petikan hasil wawancaranya:

Sebelum ujian dilaksanakan, panitia mengirimkan surat permintaan soal kepada dosen pengampu mata kuliah dan selanjutnya menyetor pada panitia pelaksana ujian akhir semester. Setelah ujian selesai dilaksanakan, naskah hasil ujian disortir untuk proses pengantaran kepada dosen pengampu mata kuliah, umumnya dosen juga dapat mengambil hasil ujiannya pada bagian administrasi akademik Pascasarjana. Mengenai jangka waktu penyetoran nilai bagi dosen umumnya sekitar 2 minggu dari jadwal ujian, dan bagi dosen yang belum menyetor nilai mendekati batas waktu yang telah ditentukan maka akan dihubungi langsung oleh bagian akademik. ${ }^{3}$

Dari hasil wawancara di atas, diperoleh informasi bahwa pelaksanaan kegiatan ujian selama ini terjadwal dan telah berjalan dengan baik dimulai dengan dosen memasukkan soal ujian yang akan diujikan pada bagian akademik baik ujian tengah semester maupun ujian akhir semester, setelah pelaksanaan ujian dialkukan dosen

${ }^{38}$ Achmad Abubakar, Wakil Direktur bidang Akademik Pascasarjana UIN Alauddin Makassar, Wawancara, Gowa, 5 Nopember 2017.

${ }^{39}$ Achmad Abubakar, Wakil Direktur bidang Akademik Pascasarjana UIN Alauddin Makassar, Wawancara, Gowa, 5 Nopember 2017. 


\section{Pelaksanaan Quality Control Proses Pembelajaran Pada Pascasarjana Universitas Islam Negeri (UIN) Alauddin Makassar}

mengambil hasil ujiannya untuk diberikan penilaian terhadap hasil ujian tersebut sampai pada penyetoran nilai yang dilakukan oleh dosen. Semua kegiatan tersebut telah terencana dengan baik, sehingga proses penilaian hasil pembelajaran ini berjalan dengan baik dan sesuai dengan ketentuan yang telah ditetapkan.

Penilaian hasil belajar yang difokuskan pada pelaksanaan kegiatan ujian akhir semester telah terjadwal dengan baik dan dilakukan secara serentak oleh panitia pelaksana ujian. Kegiatan penilaian yang dilakukan oleh dosen selama proses perkuliahan akan digabungkan menjadi nilai akhir pada saat akhir semester.

Membahas mengenai upaya yang dilakukan pascasarjana terkait pengendalian dan peningkatan mutu bagi Alumni, maka tentu berkaitan langsung dengan visi yang diemban Universitas Islam Negeri Alauddin Makassar sebagai pusat pencerahan dan transformasi ilmu pengetahuan dan teknologi berbasis peradaban. Visi ini kemudian dibedah menjadi pusat studi kajian sumber Islam dan untuk mewujudkan visi tersebut, maka Pascasarjana melakukan berbagai upaya dalam rangka mewujudkannya dengan menetapkan beberapa kebijakan terkait penyelenggaraan pendidikan, yakni Pascasarjana mengeluarkan kebijakan dalam bentuk program program unggulan yang dilakukan terhadap mahasiswa di antaranya program matrikulasi.

Hal lainnya yang memiliki hubungan yang erat dengan mutu lulusan yakni terkait ujian akhir semester, semua mahasiswa diwajibkan untuk ikut ujian akhir semester. Itulah sebabnya untuk para dosen juga diwajibkan membuat soal untuk setiap mata kuliah yang diampuhnya. Hal ini tentunya sangat penting dilakukan, olehnya itu sejak awal yakni pada kegiatan orientasi perkuliahan disampaikan kepada semua mahasiswa agar mahasiswa serius memperhatikan regulasi dan kebijakan yang diterapkan oleh Pascasarjana dengan mentaati dan menjalani setiap mekanisme pembelajaran dengan sebaik mungkin dalam hal ini tingkat kehadiran dalam pembelajaran maupun mekanisme lainnya yang diterapkan oleh dosen, sehingga penguasaan terhadap materi-materi yang terdapat dalam silabus dan RPS dapat terealisasi sepenuhnya. Di samping itu diharapkan pembelajaran tidak abal-abal sehingga menghasilkan mahasiswa dan lulusan yang berkualitas.

Selain itu, dalam rangka membekali para lulusan agar dapat memiliki kompetensi sesuai dengan bidang keilmuan yang digeluti, kebijakan lainnya yang dilakukan pihak Pascasarjana telah yakni menerapkan ujian komprehensif khusus untuk jenjang program doktoral. Sebagaimana petikan wawancara dengan wakil direktur terkait mekanisme pelaksanaan ujian komprehensif khusus untuk program doktoral, Hal ini dilakukan dengan tujuan untuk memastikan bahwa para mahasiswa menguasai materi-materi dasar dan keahlian yang berkaitan dengan ilmu Dirasah Islamiyah.

Selanjutnya, terkait dengan prosedur dan mekanisme penulisan karya ilmiah, yang menjadi syarat mutlak bagi setiap mahasiswa untuk dapat menyelesaikan Pendidikan dari tahapan pengajuan tema/judul tesis maupun disertasi, selanjutnya terkait mekanisme pengusulan judul telah dilakukan pada saat mahasiswa mendaftar di Pascasarjana sebagaimana penulis alami, di mana calon mahasiswa sudah dipersyaratkan memasukkan karya ilmiah dalam bentuk proposal berupa draft tesis dan disertasi yang diajukan untuk wawancara saat mendaftar sebagai calon mahasiswa, yang nantinya menjadi salah satu alternatif pilihan untuk menjadi kajian berupa karya ilmiah dalam bentuk tesis atau disertasi yang sesungguhnya, sehingga memudahkan para mahasiswa untuk mencari bahan-bahan tesis atau disertasi selama mereka kuliah setiap semester. Pada tahap ini mahasiswa diwajibkan mengusulkan 3 judul lengkap dengan latar belakang masalah dan rumusan masalah.

Setelah judul disetujui oleh ketua program studi dalam hal ini selaku pengelola program studi, maka selanjutnya ketua prodi mengusulkan nama-nama seorang promotor dan kopromotor untuk tesis dan untuk disertasi seorang promotor dan dua orang kopromotor. Nama-nama promotor dan kopromotor ini diajukan kepada direktur setelah mendapatkan persetujuan wadir yang ditandai dengan paraf dan persetujuan dari wakil direktur. Setelah direktur menyetujui pengajuan tersebut, selanjutnya staf membuatkan dan menerbitkan surat keputusan promotor dan kopromotor, dan 
berdasarkan legalitas surat keputusan direktur tersebut, promotor dan kopromotor menjalankan tugasnya membimbing mahasiswa hingga selesai.

Persyaratan lainnya adalah setiap mahasiswa calon magister diwajibkan mempublikasikan hasil temuannya di jurnal nasional terakreditasi sedangkan untuk mahasiswa calon doktor diwajibkan mempublikasikan hasil temuannya di jurnal internasional bereputasi, syarat ini diwajibkan pada tahun akademik 2016-2017 tetapi belum berjalan sebagaimana yang diharapkan karena perlu jeda waktu untuk mensosialisasikan kepada para mahasiswa, Persyaratan jurnal nasional dan internasional bereputasi akan diterapkan secara efektif pada tahun 2019.

Berdasarkan uraian di atas, maka dapat disimpulkan bahwa pembelajaran di Pascasarjana UIN Alauddin Makassar telah berjalan dengan baik yang dimulai dari perencanaan pembelajaran, pelaksanaan proses pembelajaran, penilaian hasil pembelajaran dengan mengacu kepada standar pelayanan administrasi dan akademik yang diterapkan maupun standar nasional Pendidikan tinggi (SNPT). Keseluruhan aspek pengendalian yang telah dilaksanakan di Pascasarjana UIN Alauddin ini telah tertuang dalam Standart Operational Procedur (SOP) dan telah mendapatkan pengakuan dari mendapatkan pengakuan mutu Certification International Komite Akreditasi Nasional (KAN) dan BM TRADA Certification UKAS Quality Management dari pemerintah Inggris, selain itu keseluruhan program studi yang diselenggarakan telah mendapatkan status Akreditasi dari Badan Akreditasi Nasional Perguruan Tinggi (BAN-PT) yakni sebanyak 3 (tiga) program studi mendapatkan predikat Akreditasi A sedangkan sebanyak 5 (lima) program studi terakreditasi dengan predikat B.

\section{PENUTUP}

Hasil penelitian terkait quality control terhadap proses pembelajaran menunjukkan bahwa pelaksanaan quality control pada perencanaan pembelajaran, pelaksanaan pembelajaran dan evaluasi hasil pembelajaran telah dilaksanakan sesuai standar yang ditetapkan baik internal maupun berdasarkan standar nasional pendidikan tinggi (SNPT), dengan indikator tersedianya program tahunan maupun semester, dan kalender akademik yang menjadi acuan dalam proses pembelajaran, penyediaan sarana dan prasarana pembelajaran, dan tersedianya RPS/Silabus. Adapun program yang dilakukan Pascasarjana terkait dengan quality control, yakni: 1) pelaksanaan rapat edukasi setiap awal tahun akademik berjalan yang bertujuan untuk mengevaluasi pembelajaran yang telah terlaksana sekaligus mendengarkan masukan-masukan dan aspirasi dosen dalam rangka peningkatan mutu dan proses penyelenggaraan pendidikan, 2) control terhadap kehadiran dosen kegiatan pembelajaran, 3) control pelaksanaan tugas dosen dengan mekanisme penilaian course evaluation survey yang terintegrasi dengan sistem informasi akademik, 3) control yang dilakukan oleh pengelola program studi terkait dengan terhadap pelaksanaan pembelajaran baik secara langsung di ruangan, maupun melalui absensi setelah perkuliahan dilaksanakan, 4) control yang dilakukan oleh ketua program studi terkait kesesuaian materi yang diberikan oleh dosen dengan silabi yang telah dibuat dan disetujui melalui instrumen jurnal perkuliahan, 5) kontrol pelaksanaan evaluasi terkait ujian yang dilaksanakan baik ujian semester maupun ujian lainnya seperti ujian kualifikasi proposal, hasil tutup maupun ujian terbuka (promosi). 


\section{DAFTAR PUSTAKA}

Al-Qur'an dan Terjemahnya

Arifin M., Kapita Selekta Pendidikan Islam ,Jakarta; Bulan Bintang, 1999.

Azhar Arsyad, Pokok Pokok Manajemen: Pengetahuan Praktis bagi Pimpinan dan Eksekutif

Edward Sallis, Manajemen Mutu Terpadu Pendidikan; Peran Strategi Pendidikan di Era Globalisasi Modern, terj. Ahmad Ali Riyadi dan Fachrurrozi, Yogyakarta, Ircisod, 2010

Effendy, Mochtar, Manajemen: Suatu Pendekatan Berdasarkan Ajaran Islam, Cet. Kedua: Jakarta; Bhratara Niaga Media: 1996

Fremont E. Kast dan James E. Rosenzwing, Oganizing and Management. Diterjemahkan oleh A. Hasjmi Ali dengan judul Organisasi dan Manajemen, Jilid II, Cet. IV; Jakarta: Bumi Aksara, 2005

George R. Terry, Guide to Management, Edisi terjemahan dengan judul Prinsip-Prinsip Manajemen oleh J. Smith D.F.M Cetakan keenam, Jakarta: PT Bumi Aksara, 2000

George R. Terry, Principle of Management, 6th Edition; Georgetown: Richard D. Irwing Inc., 2002

Jhon M. Echols dan Hassan Shadily, Kamus Inggris-Indonesia, Jakarta: PT. Gramedia 2005

John Gage Allee, Websters Dictionary, Chicago, Wilcox \& Folt Book Company, 2003

Makbuloh, Deden, Manajemen Mutu Pendidikan Islam; Model Pengembangan Teori dan Aplikasi Sistem Penjaminan Mutu Cet. I; Jakarta: PT. Raja Grafindo Persada, 2011

Moh. Kasiram, Metodologi Penelitian Kualittatif-Kuantitatif Malang; UIN Malang Press, 2008

Nasution, M. Nur, Manajemen Mutu Terpadu Manajemen Mutu Terpadu, Total Quality Management

Nasution, M. Nur, Manajemen Mutu Terpadu Manajemen Mutu Terpadu: Total Quality Management, Edisi Ketiga Cet. Pertama; Bogor; Ghalia Indonesia, 2015

Nata, Abudddin, Pendidikan dalam Persfektif Al-Qur'an, Cet. I Jakarta: Prenadamedia Group, 2016

Republik Indonesia, Undang-Undang Nomor 20 Tahun 2003 tentang Sistem Pendidikan Nasional; Bab I Pasal 3, Cet. VI; Jakarta: Sinar Grafika Offset, 2014

Republik Indonesia, Undang-Undang Nomor 20 Tahun 2003 tentang Sistem Pendidikan Nasional; Bab III Pasal 4 ayat 6,

Robert Kritiner, Management, 4th Edition; Boston: Houghton Mifflin Company, 2009

Siraj, Arifuddin, Manajemen, Cet. II: Makassar; Alauddin Press Makassar, 2008

Siswanto. Pengantar Manajemen, Jakarta. Penerbit Bumi Aksara, 2007

Sugiyono, Metode Penelitian Pendidikan; Pendekatan Kuantitatif, Kualitatif dan R\&D,

Syafaruddin. Manajemen Mutu Terpadu dalam Pendidikan; Konsep, Strategi, dan Aplikasi, h. 29

Syukron, Buyung, Implementasi Manajemen Mutu Terpadu: Studi Transformatif pada Perguruan Tinggi, Jurnal Penelitian, Vol. 10, No. 2, Agustus 2016 
Umiarso \& Imam Gojali, Manajemen Mutu Sekolah di Era Otonomi Pendidikan: Menjual Mutu Pendidikan dengan Pendekatan Quality Control bagi Pelaku Lembaga Pendidikan, Cetakan II; Jogajakarta; IRCiSoD, 2011

Usman, Husaini Manajemen: Teori, Praktik dan Riset Pendidikan, Edisi Ketiga, Cet. 2; Jakarta; Bumi Aksara, 2010. 